Gitation: González-Maldonado, Juan, García-Winder, Miguel Jorge, Cadena-Villegas, Said, Salazar-Ortiz, Juan, Gallegos-Sánchez, Jaime, \& Cortez-Romero, César. (2021). Reproductive activity of dairy cattle in the postpartum anestrus period. Agro Productividad. https://doi.org/10.32854 agrop.v14i8.2060

Editor in Ghief: Dr. Jorge Cadena Iñiguez

Received: March, 2021.

Accepted: July, 2021.

Estimated publication date: September, 2021

This work is licensed under a Creative Commons Attribution-NonCommercial 4.0 International license.

\section{Reproductive activity of dairy cattle in the postpartum anestrus period}

\author{
González-Maldonado, Juan $^{1,2}$; García-Winder, Miguel Jorge ${ }^{3}$; Cadena-Villegas, Said ${ }^{4}$; \\ Salazar-Ortiz, Juan ${ }^{5}$; Gallegos-Sánchez, Jaime ${ }^{1}$; Cortez-Romero, César ${ }^{1,6, *}$
}

1 Colegio de Postgraduados Campus Montecillo. Montecillo, Texcoco, Estado de México, México. G.P. 56230.

2 Universidad Autónoma de Baja California. Instituto de Ciencias Agrícolas, Mexicali, Baja California, México. C.P. 21705.

3 Secretaría de Relaciones Exteriores, Embajador y Representante Permanente. Agencias de las Naciones Unidas Basadas en 00161 Roma, Italia.

4 Colegio de Postgraduados Campus Tabasco, H. Cárdenas, Tabasco, México. C.P. 86500.

5 Colegio de Postgraduados Campus Córdoba, Manuel León, Amatlán de los Reyes, Veracruz, México. C.P. 94946.

${ }^{6}$ Colegio de Postgraduados Campus San Luis Potosí. Salinas de Hidalgo, San Luis Potosí, México. C.P. 78600.

* Corresponding author: ccortez@colpos.mx

\section{ABSTRACT}

Objective: To review the metabolic and hormonal processes that regulate reproductive activity in dairy cattle during the postpartum anestrus period.

Design/methodology/approach: Analysis of scientific documents and systematization of information related to the reproductive physiology and management of dairy cattle in postpartum anestrus.

Results: Postpartum anestrus is an event that occurs naturally and is necessary for restoration of the homeostasis of the cow's body following calving. However, failure to reestablish this homeostasis actually increases its duration and negatively affects the subsequent reproductive performance of the individual cow.

Limitations on study/implications: Reproductive management decisions must be based on scientific knowledge.

Findings/conclusions: Management of dairy cattle in the postpartum anestrus period should focus on reestablishment of the state of homeostasis and the subsequent reproductive activity, with nutritional and hormonal strategies implemented to induce cyclicity, ovulation and formation of the first corpus luteum in that period, through application of exogenous hormones after day ten postpartum.
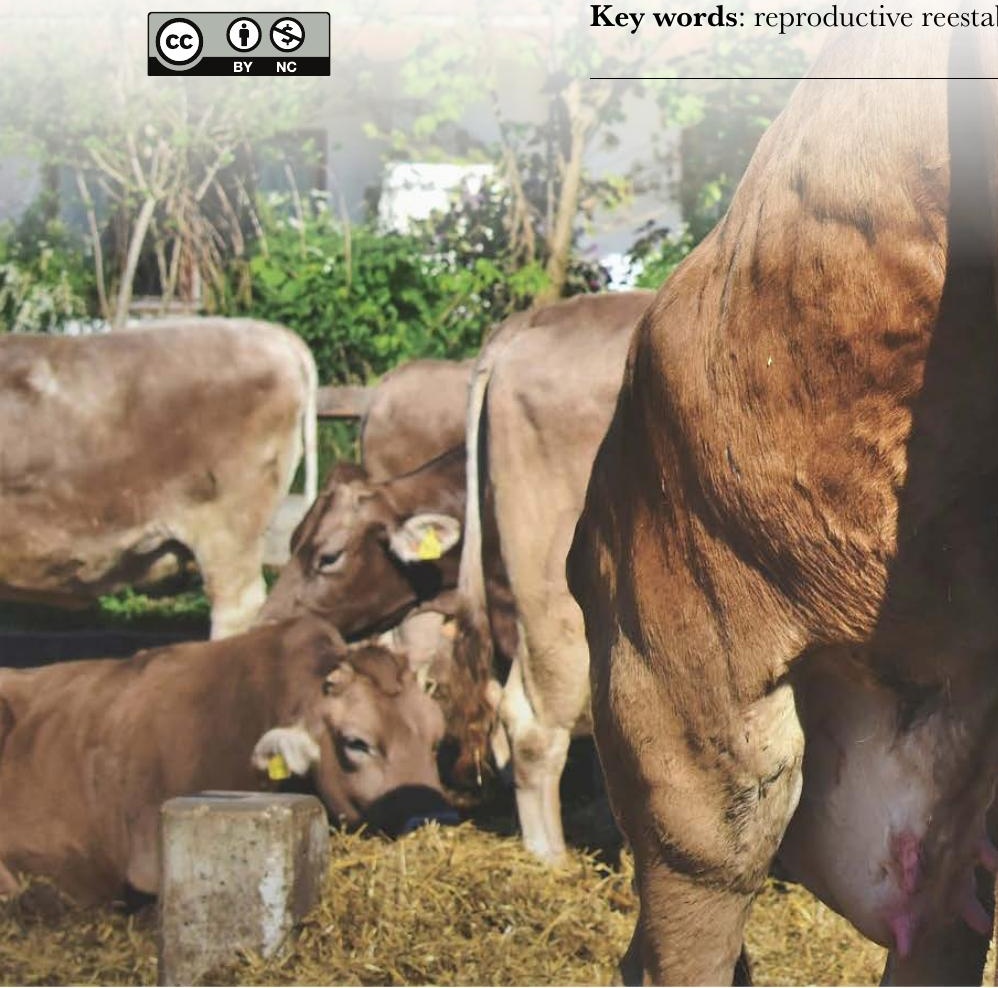

Key words: reproductive reestablishment, follicular development, ovulation. 


\section{INTRODUCTION}

Cows can live for more than 15 years, but their life expectancy is significantly reduced (by 3-4 years) within specialized dairy production units (DPU), with reproductive failure one of the main causes (De Vries, 2020).

The predisposing factors for poor reproductive performance in cows after calving include poor corporal condition, caloric stress and postpartum diseases. This can represent an annual economic loss of approximately $\$ 622.00$ dollars per cow (Kim \& Jeong, 2019) peri- and postpartum disorders, body condition score (BCS. This is added to the historic decline in cattle fertility caused by genetic selection towards greater milk production, although reproductive characteristics are now included within the genetic improvement programs (Kgari et al., 2020).

Postpartum anestrus is one of the most dynamic periods in the reproductive life of the dairy cow. It is of natural occurrence, and is characterized by the absence of estrus (Ambrose, 2021). The postpartum normalization of reproductive activity is certainly of vital importance to achieve early gestation, but it is necessary to understand the main events that trigger postpartum anestrus in order to implement management strategies that can contribute to reducing its duration. The objective of this study is therefore to review the metabolic and hormonal processes that regulate the reproductive activity of the dairy cow during the period of postpartum anestrus.

\section{Hormonal and metabolic profile of the postpartum cow}

During postpartum, cows present a period of negative energetic balance that can last up to 140 days (Beever et al., 1998). The lag between the rapid increase in the production of milk and the gradual increase in the consumption capacity of the cow is its main trigger. In turn, this causes a mobilization of corporal reserves, and loss of corporal condition (Figure 1). The energy provided by the corporal reserves is used to maintain vital physiological functions, since the loss of sensitivity to insulin on the part of peripheral tissues during postpartum favors consumption of glucose by the udder (Habel \& Sundrum, 2020).

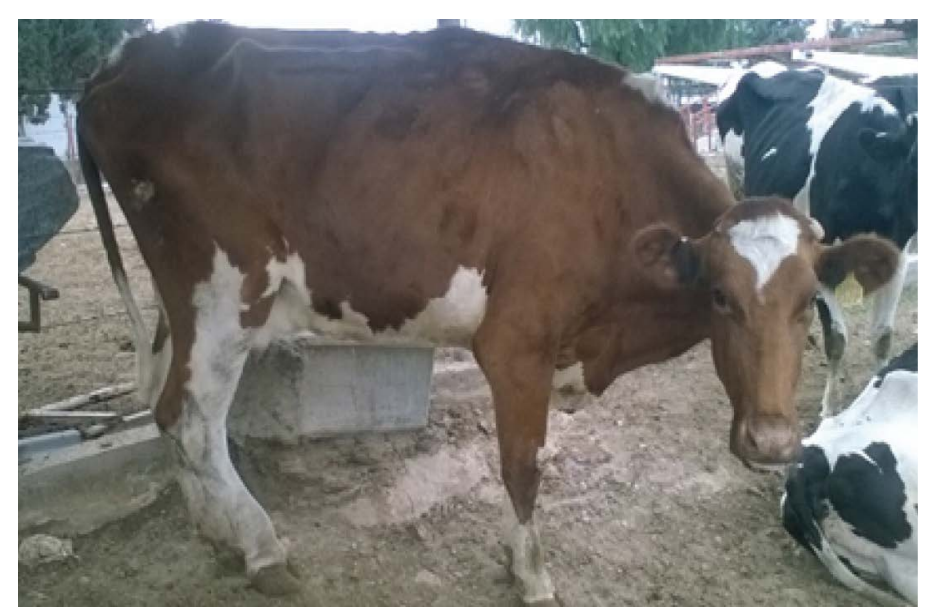

Figure 1. Dairy cow presenting poor corporal condition. 
The cow presents a state of hypoinsulinemia in postpartum (Weber et al., 2016), associated with a reduction in the hepatic expression of receptors of growth hormones (GH, Rhoads et al., 2004) and causing an increase in the blood concentrations of the GH and a reduction in those of the factor analogous to insulin (IGF-I, Fenwick et al., 2008). The GH, through lack of linkage with their hepatic receptors, promote lipolysis (Silva et al., 2017) causing increased blood concentrations of non-esterified fatty acids (NEFA), such as palmitic and stearic acid (Contreras et al., 2010), which can be used as energy sources and in the formation of ketone bodies.

Secretion of ghrelin increases during fasting, dietary restriction and postpartum (Nowroozi-Asl et al., 2016). It is likely that this hormone promotes postpartum lipolysis, since it can stimulate the secretion of GH (Itoh et al., 2005). On the other hand, the concentrations of leptin, produced by the adipocytes, decrease as a result of the loss of corporal condition (Liefers et al., 2003). The concentration patterns of both hormones, and those of insulin, are used as signals to stimulate the appetite, through the release of neuropeptide Y (NPY, Nowroozi-Asl et al., 2016), since an increase in its concentration is associated with greater consumption of food by the cow during postpartum (Gaowa $e t$ al., 2021). For this reason, following calving, the cow presents a hormonal and metabolic response directed towards developing a state of homeostasis between the quantity of nutrients available and the production of milk.

\section{Ovarian activity of the cow during postpartum}

The effects of the events that occur during postpartum, in terms of the reproductive functions of the cow, depend to a large extent on the quantity of milk that is being produced and the severity of the loss of corporal condition. The first dominant follicle can be observed from the seventh day after calving (Tanaka et al., 2008), but the first ovulation is not produced until 18 to 57 days after calving in cows of high milk production (Sakaguchi et al., 2004). In cows of low milk production, however, this takes place at 17 to 35 days after calving (Kawashima et al., 2007). The delayed appearance of the first postpartum ovulation, or indeed the lack of ovulation, has been related to reduced steroidogenic follicular capacity, low frequency of luteinizing hormone (LH) and low consumption of food (Cheong et al., 2016). Moreover, cows that present a rapid loss of corporal condition during postpartum present a reduced follicular population (Walters et al., 2002), which is associated with a delay of up to 20 days in the appearance of the first ovulation (Furukawa et al., 2020).

The state of hypoinsulinemia during postpartum is undoubtedly prejudicial to ovarian activity. The insulin promotes the proliferation of granulosa cells and the production of estradiol (Gutiérrez et al., 1997). It has also been reported that the preovulatory follicles contain greater concentrations of this hormone than the subordinate follicles (Landau $e t$ al., 2000), probably due to the fact that this is important for completion of the cascade of events that lead to ovulation (Sekulovski et al., 2020). This helps to explain the lack of ovulation or its delay in cows in the postpartum. For its part, the IGF-I is necessary for follicular development and promotes cellular proliferation, the expression of gonadotropin receptors and the production of estradiol (Zhou et al., 1997; Mani et al., 2010). This suggests 
that the low concentrations of IGF-I observed during the postpartum are undesirable in terms of follicular activity.

The maturation, culture and fertilization of oocytes, in the presence of concentrations of palmitic and stearic acid similar to those found in the follicles of cows of high milk production during postpartum, increases the apoptosis of the cells of the clusters and reduces the level of competition of the oocyte (Leroy et al., 2005). In contrast, in cows that are not in a negative energetic balance, intra-follicular injection of these acids temporarily reduces the follicular size, but not the steroidogenic activity (Ferst $e$ t al., 2020). This suggests that the effect of the NEFA is dependent on the energetic balance of the cow.

\section{Uterine health of postpartum cows and its effect on reproductive function}

Uterine infections are common during postpartum. However, the probability that a cow becomes pregnant following its first insemination postpartum is four times lower in cows that suffered an infection than it is in healthy individuals (Gobikrushanth et al., 2016). This is possibly due to the presence of high intra-follicular concentrations of endotoxins (Cheong et al., 2017), since the intra-follicular injection of bacterial products (lipopolysaccharides) reduces the number of ovulations (Gindri et al., 2019).

The addition of follicular liquid of cows with subclinical uterine infection in the middle of the culture acts to diminish the competition of the oocyte, because of a high concentration of lipopolysaccharides (Heidari et al., 2019). This could be due to the fact that these induce an inflammatory response and an oxidative stress (Zhao et al., 2019), as well as altering the nuclear and cytoplasmic maturation in the oocyte (Magata \& Shimizu, 2017).

\section{Nutritional and hormonal strategies to break postpartum anestrus}

Nutritional and hormonal strategies to shorten or to break postpartum anestrus are directed towards reestablishing the hormonal and metabolic balance of the cow. Restoration of the blood concentrations of insulin is perhaps one of the main objectives. Supplementation with propylene glycol in postpartum is effective in terms of increasing the blood concentration of insulin, while reducing those of NEFA and ketone bodies (Rizos et al., 2008). In addition, to improve fertility, it is recommended to establish a pattern of feeding that allows an increase in the blood concentrations of this hormone in the first days postpartum, with the subsequent provision of a diet that allows the reduction of these concentrations (Garnsworthy et al., 2009).

There is a large quantity of scientific information that addresses the application of hormones to induce postpartum cyclicity(Rhodes et al., 2003). Hormonal strategies to induce this generally include the use of progestogens, estradiol and GnRH. The progestogens are used to sensitize the hypothalamus to the effect of the estradiol following calving, such that the female can exhibit the behavior of estrus (Figure 2; Nagai et al., 2013).

On the other hand, the LH content in the pituitary remains low between days one and 15 compared to that of day 30 postpartum, while the quantity of GnRH receptors increases at 15 days after calving (Nett et al., 1988). This explains the absence of a peak in $\mathrm{LH}$ in response to the injection of $\mathrm{GnRH}$ within the first eight days postpartum (Peters $e t$ al., 1985), although it has been observed that the response tends to normalize after day ten 

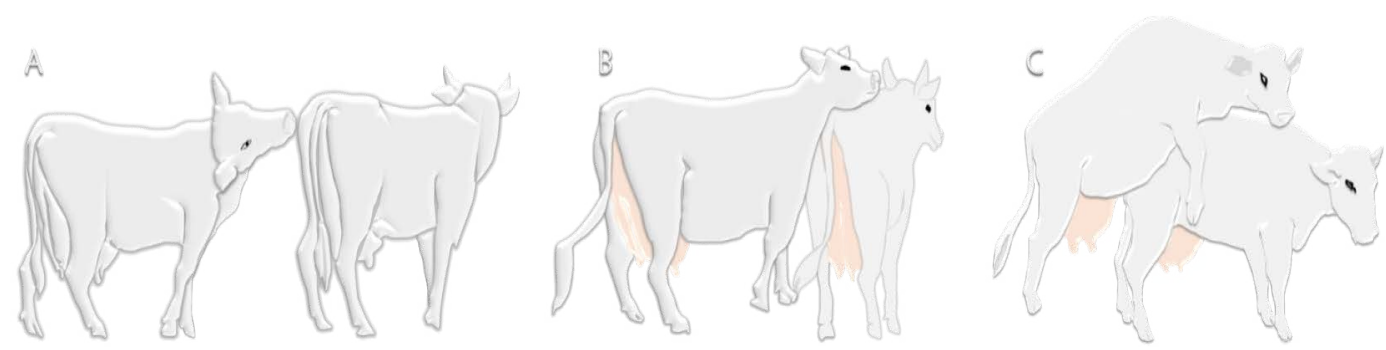

Figure 2. Secondary signs of estrus. A: the cow sniffs its companions. B: the cow rests its head on the back of another. C: primary sign of estrus; the cow accepts being mounted by another and is then considered to be in estrus.

(Fernandes et al., 1978), for which reason it is recommended to begin the treatments after day ten postpartum.

\section{CONGLUSIONS}

Management of dairy cattle in postpartum should be focused on reestablishing the state of homeostasis, and then reproductive activity, for which reason the nutrition, health, well being and reproduction should be coordinated into a single management strategy; mainly featuring nutritional and hormonal strategies designed to induce cyclicity with ovulation and formation of the first corpus luteum in the postpartum period, through the use of progesterone, estradiol and GnRH after day ten postpartum.

\section{REFERENCES}

Ambrose D. J. (2021). Pospartum anestrus and its maganement in dairy cattle. In R. M. Hopper (Ed) Bovine Reproduction (pp 408-430). Wiley Online Library. Doi: 10.1002/9781119602484.ch34

Beever, D. ., Cammell, S. B., Sutton, J. D., Rowe, N., \& Perrott, G. E. (1998). Energy metabolism in high yielding cows. Proceedings of the British Society of Animal Science, 1998, 13-13. Doi:10.1017/s0308229600032268

Cheong, S. H., Filho, O. G. S., Absalon-Medina, V. A., Schneider, A., Butler, W. R., \& Gilbert, R. O. (2017). Uterine and systemic inflammation influences ovarian follicular function in postpartum dairy cows. PLoS ONE, 12(5), 1-16. Doi: 10.1371/journal.pone.0177356

Cheong, S. H., Sá Filho, O. G., Absalón-Medina, V. A., Pelton, S. H., Ronald Butler, W., \& Gilbert, R. O. (2016). Metabolic and endocrine differences between dairy cows that do or do not ovulate first postpartum dominant follicles. Biology of Reproduction, 94(1). Doi: 10.1095/biolreprod.114.127076

Contreras, G. A., O’Boyle, N. J., Herdt, T. H., \& Sordillo, L. M. (2010). Lipomobilization in periparturient dairy cows influences the composition of plasma nonesterified fatty acids and leukocyte phospholipid fatty acids. Journal of Dairy Science, 93(6), 2508-2516. Doi: 10.3168/jds.2009-2876

De Vries, A. (2020). Symposium review: Why revisit dairy cattle productive lifespan? Journal of Dairy Science, 103(4), 3838-3845. Doi: 10.3168/jds.2019-17361

Fenwick, M. A., Fitzpatrick, R., Kenny, D. A., Diskin, M. G., Patton, J., Murphy, J. J., Wathes, D. C. (2008). Interrelationships between negative energy balance (NEB) and IGF regulation in liver of lactating dairy cows. Domestic Animal Endocrinology, 34(1), 31-44. Doi: 10.1016/j.domaniend.2006.10.002

Fernandes, L. C., Thatcher, W. W., Wilcox, G. J., Call, E. P. (1978). LH Release in response to GnRH during the postpartum period of dairy cows. Journal of Animal Science, 46(2), 443-448. Doi: 10.2527/ jas 1978.462443x

Ferst, J. G., Missio, D., Bertolin, K., Gasperin, B. G., Leivas, F. G., Bordignon, V., Gonçalves, P. B., Ferreira, R. (2020). Intrafollicular injection of nonesterified fatty acids impaired dominant follicle growth in cattle. Animal Reproduction Science, 219, 106536. Doi: 10.1016/j.anireprosci.2020.106536

Furukawa, E., Masaki, T., Sakaguchi, K., Bo, M., Yanagawa, Y., Ueda, K., Nagano, M. (2020). Relationship between the timing of the first postpartum ovulation and antral follicle counts in Holstein cows. Journal of Ovarian Research, 13(1), 1-9. Doi: 10.1186/s13048-020-0610-5 
Gaowa, N., Zhang, X., Li, H., Wang, Y., Zhang, J., Hao, Y., Cao, Z., Li, S. (2021). Bacterial Community in Multiparous Holstein Dairy Cow during the Postpartum Period. Animals, 11(3), 617. Doi: 10.3390/ anil 1030617

Garnsworthy, P. C., Fouladi-Nashta, A. A., Mann, G. E., Sinclair, K. D., Webb, R. (2009). Effect of dietaryinduced changes in plasma insulin concentrations during the early post partum period on pregnancy rate in dairy cows. Reproduction, 137(4), 759-768. Doi: 10.1530/REP-08-0488

Gindri, P., de Ávila Castro, N., Mion, B., Garziera Gasperin, B., Catarelli Pegoraro, L. M., Alveiro Alvarado Rincón, J., Diniz Vieira, A., Pradieé, J., Machado Pfeifer, L. F., Nunes Corrêa, M., Schneider, A. (2019). Intrafollicular lipopolysaccharide injection delays ovulation in cows. Animal Reproduction Science, 217(September), 106226. Doi: 10.1016/j.anireprosci.2019.106226

Gobikrushanth, M., Salehi, R., Ambrose, D. J., Colazo, M. G. (2016). Categorization of endometritis and its association with ovarian follicular growth and ovulation, reproductive performance, dry matter intake, and milk yield in dairy cattle. Theriogenology, 86(7), 1842-1849. Doi: 10.1016/j. theriogenology.2016.06.003

Gutiérrez, C. G., Campbell, B. K., Webb, R. (1997). Development of a long-term bovine granulosa cell culture system: Induction and maintenance of estradiol production, response to follicle- stimulating hormone, and morphological characteristics. Biology of Reproduction, 56(3), 608-616. Doi: 10.1095/ biolreprod56.3.608

Habel, J., Sundrum, A. (2020). Mismatch of glucose allocation between different life functions in the transition period of dairy cows. Animals, 10(6), 1-21. Doi: 10.3390/ani10061028

Heidari, M., Kafi, M., Mirzaei, A., Asaadi, A., Mokhtari, A. (2019). Effects of follicular fluid of preovulatory follicles of repeat breeder dairy cows with subclinical endometritis on oocyte developmental competence. Animal Reproduction Science, 205, 62-69. Doi:10.1016/j.anireprosci.2019.04.004

Itoh, F., Komatsu, T., Yonai, M., Sugino, T., Kojima, M., Kangawa, K., Hasegawa, Y., Terashima, Y., Hodate, K. (2005). GH secretory responses to ghrelin and GHRH in growing and lactating dairy cattle. Domestic Animal Endocrinology, 28(1), 34-45. Doi:10.1016/j.domaniend.2004.06.001

Kawashima, Chiho, Fukihara, S., Maeda, M., Kaneko, E., Montoya, C. A., Matsui, M., Shimizu, T., Matsunaga, N., Kida, K., Miyake, Y.-I., Schams, D., Miyamoto, A. (2007). Relationship between metabolic hormones and ovulation of dominant follicle during the first follicular wave post-partum in high-producing dairy cows. Reproduction, 133(1), 155-163. Doi: 10.1530/REP-06-0046

Kgari, R. D., Muller, C. J. C., Dzama, K., Makgahlela, M. L. (2020). Evaluation of female fertility in dairy cattle enterprises - A review. Arquivos Brasileiros de Psicologia, 50(6), 819-829. Doi: 10.4314/sajas. v50i6.8

Kim, I. H., Jeong, J. K. (2019). Risk factors limiting first service conception rate in dairy cows and their economic impact. Asian-Australasian Journal of Animal Sciences, 32(4), 519-526. Doi: 10.5713/ajas.18.0296

Landau, S., Braw-Tal, R., Kaim, M., Bor, A., Bruckental, I. (2000). Preovulatory follicular status and diet affect the insulin and glucose content of follicles in high-yielding dairy cows. Animal Reproduction Science, 64(3-4), 181-197. Doi: 10.1016/S0378-4320(00)00212-8

Leroy, J. L. M. R., Vanholder, T., Mateusen, B., Christophe, A., Opsomer, G., de Kruif, A., Genicot, G., Van Soom, A. (2005). Non-esterified fatty acids in follicular fluid of dairy cows and their effect on developmental capacity of bovine oocytes in vitro. Reproduction, 130(4), 485-495. Doi: 10.1530/ rep. 1.00735

Liefers, S. C., Veerkamp, R. F., Te Pas, M. F. W., Delavaud, C., Chilliard, Y., Van Der Lende, T. (2003). Leptin concentrations in relation to energy balance, milk yield, intake, live weight, and estrus in dairy cows. Journal of Dairy Science, 86,(3), 799-807. Doi: 10.3168/jds.S0022-0302(03)73662-5

Magata, Fumie, Shimizu, T. (2017). Effect of lipopolysaccharide on developmental competence of oocytes. In Reproductive Toxicology 71, 1-7. Doi: 10.1016/j.reprotox.2017.04.001

Mani, A. M., Fenwick, M. A., Cheng, Z., Sharma, M. K., Singh, D., Wathes, D. C. (2010). IGF1 induces up-regulation of steroidogenic and apoptotic regulatory genes via activation of phosphatidylinositoldependent kinase/AKT in bovine granulosa cells. Reproduction, 139(1), 139-151. Doi:10.1530/REP09-0050

Nagai, K., Endo, N., Tanaka, T., Kamomae, H. (2013). Exposure to estrogen mimicking the level of late pregnancy suppresses estrus subsequently induced by estrogen at the level of the follicular phase in Ovariectomized Shiba goats. Journal of Reproduction and Development, 59(2), 123-130. Doi: 10.1262/ jrd.2012-140

Nett, T. M., Cermak, D., Braden, T., Manns, J., Niswender, G. (1988). Pituitary receptors for GnRH and estradiol, and pituitary content of gonadotropins in beef cows. II. Changes during the postpartum period. Domestic Animal Endocrinology, 5(1), 81-89. Doi: 10.1016/0739-7240(88)90029-X 
Nowroozi-Asl, A., Aarabi, N., Rowshan-Ghasrodashti, A. (2016). Ghrelin and its correlation with leptin, energy related metabolites and thyroidal hormones in dairy cows in transitional period. Polish Journal of Veterinary Sciences, 19(1), 197-204. Doi: 10.1515/pjvs-2016-0024

Peters, A. R., Pimentel, M. G., Lamming, G. E. (1985). Hormone responses to exogenous GnRH pulses in post-partum dairy cows. Reproduction, 75(2), 557-565. Doi: 10.1530/jrf.0.0750557

Rhoads, R. P., Kim, J. W., Leury, B. J., Baumgard, L. H., Segoale, N., Frank, S. J., Bauman, D. E., Boisclair, Y. R. (2004). Insulin increases the abundance of the growth hormone receptor in liver and adipose tissue of periparturient dairy cows. Journal of Nutrition, 134(5), 1020-1027. Doi: 10.1093/jn/134.5.1020

Rhodes, F. M., McDougall, S., Burke, C. R., Verkerk, G. A., Macmillan, K. L. (2003). Invited review: Treatment of cows with an extended postpartum anestrous interval. Journal of Dairy Science, 86(6), 1876-1894. Doi: 10.3168/jds.S0022-0302(03)73775-8

Rizos, D., Kenny, D. A., Griffin, W., Quinn, K. M., Duffy, P., Mulligan, F. J., Roche, J. F., Boland, M. P., Lonergan, P. (2008). The effect of feeding propylene glycol to dairy cows during the early postpartum period on follicular dynamics and on metabolic parameters related to fertility. Theriogenology, 69(6), 688-699. Doi: 10.1016/j.theriogenology.2007.12.001

Sakaguchi, M., Sasamoto, Y., Suzuki, T., Takahashi, Y., Yamada, Y. (2004). Postpartum ovarian follicular dynamics and estrous activity in lactating dairy cows. Journal of Dairy Science, 87(7), 2114-2121. Doi: 10.3168/jds.S0022-0302(04)70030-2

Sekulovski, N., Whorton, A. E., Shi, M., Hayashi, K., MacLean, J. A. (2020). Periovulatory insulin signaling is essential for ovulation, granulosa cell differentiation, and female fertility. FASEB Journal, 34(2), 2376 2391. Doi: 10.1096/fj.201901791R

Silva, P. R. B., Soares, H. F., Braz, W. D., Bombardelli, G. D., Clapper, J. A., Keisler, D. H., Chebel, R. C. (2017). Effects of treatment of periparturient dairy cows with recombinant bovine somatotropin on health and productive and reproductive parameters. Journal of Dairy Science, 100(4), 3126-3142. Doi: $10.3168 /$ jds.2016-11737

Tanaka, T., Arai, M., Ohtani, S., Uemura, S., Kuroiwa, T., Kim, S., Kamomae, H. (2008). Influence of parity on follicular dynamics and resumption of ovarian cycle in postpartum dairy cows. Animal Reproduction Science, 108(1-2), 134-143. Doi: 10.1016/j.anireprosci.2007.07.013

Walters, A. H., Bailey, T. L., Pearson, R. E., Gwazdauskas, F. G. (2002). Parity-related changes in bovine follicle and oocyte populations, oocyte quality, and hormones to 90 days postpartum. Journal of Dairy Science, 85(4), 824-832. Doi: 10.3168/jds.S0022-0302(02)74142-8

Weber, C., Schäff, C. T., Kautzsch, U., Börner, S., Erdmann, S., Görs, S., Röntgen, M., Sauerwein, H., Bruckmaier, R. M., Metges, C. C., Kuhla, B., Hammon, H. M. (2016). Insulin-dependent glucose metabolism in dairy cows with variable fat mobilization around calving. Journal of Dairy Science, 99(8), 6665-6679. Doi: 10.3168/jds.2016-11022

Zhao, S., Pang, Y., Zhao, X., Du, W., Hao, H., Zhu, H. (2019). Detrimental effects of lipopolysaccharides on maturation of bovine oocytes. Asian-Australasian Journal of Animal Sciences, 32(8), 1112-1121. Doi: 10.5713/ajas. 18.0540

Zhou, J., Kumar, T. R., Matzuk, M. M., Bondy, C. (1997). Insulin-like growth factor I regulates gonadotropin responsiveness in the murine ovary. Molecular Endocrinology, 11(13), 1924-1933. Doi: 10.1210/ mend.11.13.0032 